\title{
GABAergic Spill-Over Transmission onto Hippocampal Mossy Fiber Boutons
}

\author{
Henrik Alle and Jörg R. P. Geiger \\ Independent Hertie Research Group, Max Planck Institute for Brain Research, D-60528 Frankfurt, Germany
}

\begin{abstract}
Presynaptic ionotropic $\mathrm{GABA}_{\mathrm{A}}$ receptors have been suggested to contribute to the regulation of cortical glutamatergic synaptic transmission. Here, we analyzed presynaptic $\mathrm{GABA}_{\mathrm{A}}$ receptor-mediated currents $\left(34^{\circ} \mathrm{C}\right)$ recorded from mossy fiber boutons (MFBs) in rat hippocampal slices. In MFBs from young and adult animals, GABA puff application activated currents that were blocked by $\mathrm{GABA}_{\mathrm{A}}$ receptor antagonists. The conductance density of $0.65 \mathrm{mS} \cdot \mathrm{cm}^{2}$ was comparable to that of other presynaptic terminals. The singlechannel conductance was $36 \mathrm{pS}$ (symmetrical chloride), yielding an estimated $\mathrm{GABA}_{\mathrm{A}}$ receptor density of $20-200$ receptors per MFB. Presynaptic $\mathrm{GABA}_{\mathrm{A}}$ receptors likely contain $\alpha_{2}$-subunits as indicated by their zolpidem sensitivity. In accordance with the low apparent GABA affinity $\left(\mathrm{EC}_{50}=60 \mu \mathrm{M}\right)$ of the receptors and a tight control of ambient GABA concentration by GABA transporters, no tonic background activation of presynaptic $\mathrm{GABA}_{\mathrm{A}}$ receptors was observed. Instead, extracellular high-frequency stimulation led to transient presynaptic currents, which were blocked by $\mathrm{GABA}_{\mathrm{A}}$ receptor antagonists but were enhanced by block of GAT 1 (GABA transporter 1), indicating that these currents were generated by GABA spill-over and subsequent presynaptic $\mathrm{GABA}_{\mathrm{A}}$ receptor activation. Presynaptic spill-over currents were depressed by pharmacological cannabinoid 1 (CB1) receptor activation, suggesting that GABA was released predominantly by a $\mathrm{CB} 1$ receptor-expressing interneuron subpopulation. Because $\mathrm{GABA}_{\mathrm{A}}$ receptors in axons are considered to act depolarizing, high activity of $\mathrm{CB} 1$ receptor-expressing interneurons will exert substantial impact on presynaptic membrane potential, thus modulating action potential-evoked transmitter release at the mossy fiber-CA3 synapse.
\end{abstract}

Key words: hippocampal mossy fiber; presynaptic; $\mathrm{GABA}_{\mathrm{A}}$ receptor; spill-over; zolpidem; GAT

\section{Introduction}

Fast chemical synaptic signaling in the nervous system is performed by presynaptic transmitter release and the activation of postsynaptic ligand-gated ion channels. In addition, there is $\mathrm{cu}-$ mulating evidence for axonal and presynaptic ligand-gated ion channels modulating axonal signaling and transmitter release (Engelman and MacDermott, 2004).

Particularly strong evidences exist for a widespread expression of presynaptic or axonal ionotropic GABA-gated receptor channels $\left(\mathrm{GABA}_{\mathrm{A}}\right.$ receptors) in subcortical and cortical brain regions (Eccles et al., 1963; Zhang and Jackson, 1993; Jang et al., 2001; Turecek and Trussell, 2002; Ruiz et al., 2003; Jang et al., 2005, 2006). $\mathrm{GABA}_{\mathrm{A}}$ receptors are permeable to anions and assumed to act mainly inhibitory (Alger and Nicoll, 1979). In axons and presynaptic terminals, their activation leads to a depolarization (Eccles et al., 1963; Zhang and Jackson, 1993; Jang et al., 2006; Szabadics et al., 2006) because of higher chloride concentrations in these compartments (Zhang and Jackson, 1993; Price and Trussell, 2006; Szabadics et al., 2006). It has been suggested that

Received Nov. 17, 2006; revised Dec. 18, 2006; accepted Dec. 19, 2006.

This work was supported by the Hertie Foundation, the Deutsche Forschungsgemeinschaft, and the Max Planck Society. We thank I. Wüllenweber for technical assistance.

Correspondence should be addressed to Jörg R. P. Geiger, Independent Hertie Research Group, Max Planck Institute for Brain Research, Deutschordenstrasse 46, D-60528 Frankfurt, Germany. E-mail: geiger@mpih-frankfurt.mpg.de.

DOI:10.1523/JNEUROSCI.4996-06.2007

Copyright $\odot 2007$ Society for Neuroscience $\quad$ 0270-6474/07/270942-09\$15.00/0 axonal depolarization can lead either to reduction (Eccles et al., 1963; Zhang and Jackson, 1993) or enhancement (Jang et al., 2001, 2005, 2006; Turecek and Trussell, 2002; Ruiz et al., 2003) of transmitter release depending on the synapse studied. The mechanisms mediating transmitter release regulation range from modulation of action potential (AP) shape and AP propagation block (Zhang and Jackson, 1993; Jackson and Zhang, 1995) to AP-independent effects (Turecek and Trussell, 2001; Awatramani et al., 2005; Kullmann et al., 2005). Despite the widespread presynaptic expression of $\mathrm{GABA}_{\mathrm{A}}$ receptors, little is known about the pharmacological and functional properties of presynaptic $\mathrm{GABA}_{\mathrm{A}}$ receptors and the requirements for their physiological activation, especially in cortical regions of the brain.

Recent evidences suggested that $\mathrm{GABA}_{\mathrm{A}}$ receptors are also expressed in hippocampal mossy fibers (Ruiz et al., 2003; Jang et al., 2006). In one study using hippocampal slices from guinea pigs (Ruiz et al., 2003), it has also been suggested that $\mathrm{GABA}_{\mathrm{A}}$ receptors in mossy fibers are permanently activated, indicating a high affinity for GABA and a contribution to the regulation of steadystate axonal and presynaptic membrane potential.

In one of our previous studies, however, the resting membrane potential of mossy fibers measured by direct patch-clamp recordings from mossy fiber boutons (MFBs) was found to be independent of the chloride concentration in the intracellular recording solutions (Geiger and Jonas, 2000). This conflicts with the idea of permanently activated presynaptic chloridepermeable conductances in rat mossy fibers. Thus, we used the 
presynaptic recording technique to study presynaptic $\mathrm{GABA}_{\mathrm{A}}$ receptor-mediated signaling directly. We investigated the persistence of $\mathrm{GABA}_{\mathrm{A}}$ receptor-mediated currents during development and the functional and pharmacological properties of presynaptic $\mathrm{GABA}_{\mathrm{A}}$ receptors. We directly demonstrated presynaptic $\mathrm{GABA}_{\mathrm{A}}$ receptor-mediated currents activated by spill-over of synaptically released GABA from a specific interneuron population. Finally, simulations illustrate the impact of transient $\mathrm{GABA}_{\mathrm{A}}$ receptor-mediated spill-over transmission on presynaptic and axonal membrane potential.

\section{Materials and Methods}

Slice preparation. Wistar rats aged 12-14 d, 3-4 weeks, and 3 months were anesthetized with isoflurane and decapitated according to institutional guidelines. Transverse $300-\mu \mathrm{m}$-thick hippocampal slices were cut using a custom-built vibratome (Geiger et al., 2002; Bischofberger et al., 2006). For dissection and storage of slices, the following solution was used (in mM): $75 \mathrm{NaCl}, 25 \mathrm{NaHCO}_{3}, 1.25 \mathrm{NaH}_{2} \mathrm{PO}_{4}, 4 \mathrm{KCl}, 25$ glucose, 100 sucrose, $0.5 \mathrm{CaCl}_{2}$, and $3 \mathrm{MgCl}_{2}$, equilibrated with $95 \% \mathrm{O}_{2} / 5 \% \mathrm{CO}_{2}$. Slices were incubated at $33^{\circ} \mathrm{C}$ for $30 \mathrm{~min}$ and subsequently stored at room temperature.

Recording solutions. Slices were superfused with a physiological extracellular solution [artificial CSF (ACSF)] containing (in mM) $125 \mathrm{NaCl}, 25$ $\mathrm{NaHCO}_{3}, 1.25 \mathrm{NaH}_{2} \mathrm{PO}_{4}, 2.5 \mathrm{KCl}, 25$ glucose, $2 \mathrm{CaCl}_{2}$, and $1 \mathrm{MgCl}_{2}$, equilibrated with $95 \% \mathrm{O}_{2} / 5 \% \mathrm{CO}_{2}$. HEPES-buffered ACSF, used for local drug application, contained the following (in mM): 5 HEPES, 145 $\mathrm{NaCl}, 1.25 \mathrm{NaH}_{2} \mathrm{PO}_{4}, 2.5 \mathrm{KCl}, 25$ glucose, $1.8 \mathrm{CaCl}_{2}$, and $1 \mathrm{MgCl}_{2}, \mathrm{pH}$ 7.35. In all recordings, $1 \mu \mathrm{M}$ CGP 52432 (3-[[(3,4-dichlorophenyl)methyl]amino]propyl] (diethoxymethyl)phosphinic acid) was added to the ACSF and to the HEPES-buffered ACSF.

For MFB recordings (see Figs. 1, $2 B, C, 3,4 B, 5,6$ ) in the whole-cell mode, pipettes were filled with a solution containing the following (in $\mathrm{mm}): 140 \mathrm{KCl}, 2 \mathrm{MgCl}_{2}, 10 \mathrm{HEPES}, 2 \mathrm{Na}_{2}$-ATP, and 10 EGTA. Intracellular solutions in Fig. $2 \mathrm{~A}$ contained the following (in $\mathrm{mM}$ ): $2 \mathrm{MgCl}_{2}, 10$ HEPES, $2 \mathrm{Na}_{2}$-ATP, 10 EGTA, and either $6 \mathrm{CsCl}$ and 140 cesiummethanesulfonate ("low" chloride solution) or $130 \mathrm{CsCl}$ and 15 cesiummethanesulfonate ("high" chloride solution), which was also used in Figure $5 C$. The intracellular solution in Fig. $4 \mathrm{~A}$ contained the following (in mM): $125 \mathrm{~K}$-gluconate, $20 \mathrm{KCl}, 2 \mathrm{MgCl}_{2}, 10 \mathrm{HEPES}, 2 \mathrm{Na}_{2}$-ATP, and 10 EGTA. In all intracellular solutions, $\mathrm{pH}$ was set to 7.2.

Electrophysiology. Patch pipettes for MFB recordings were pulled from thick-walled borosilicate glass tubing and had resistances of 7-12 $\mathrm{M} \Omega$. Signals were recorded with a Multiclamp $700 \mathrm{~A}$, filtered at $1-6 \mathrm{kHz}$, and digitized at $10-20 \mathrm{kHz}$ using Digidata1322; data acquisition and analysis were performed using pClamp 8.2 (Molecular Devices, Sunnyvale, CA). Hippocampal CA3 MFBs in the stratum lucidum were identified visually (the apparent diameter in the infrared differential interference contrast video microscopy was 3-5 $\mu \mathrm{m}$ ) (see Fig. $1 A$ ), and the visual identification was confirmed electrophysiologically as follows: (1) they exhibit a fast capacitive transient in response to a $10 \mathrm{mV}$ voltage step in the voltage-clamp mode and have (2) a small whole-cell capacitance $(\sim 1-2$ $\mathrm{pF}),(3)$ a high input resistance $(>1 \mathrm{G} \Omega),(4)$ an instantaneous fast sodium current in response to a suprathreshold voltage step, (5) a characteristic AP waveform recorded in the current-clamp mode with halfdurations $<500 \mu \mathrm{s}\left(\right.$ at $34^{\circ} \mathrm{C}$ ) with a fast repolarization, slow afterdepolarization sequence (Geiger and Jonas, 2000; Bischofberger et al. 2006), and (6) no spontaneous synaptic events. These distinguish them clearly from CA3 pyramidal dendrites [slow capacitive transient, large whole-cell capacitance, low input resistance $(<250 \mathrm{M} \Omega)$, delayed slow sodium current, APs with half-durations $>800 \mu$ s at $34^{\circ} \mathrm{C}$, spontaneous synaptic events] (for comparison, see supplemental Fig. 1, available at www.jneurosci.org as supplemental material), interneuron dendrites (large whole-cell capacitance, low input resistance, sustained highfrequency AP pattern, fast spontaneous synaptic events), or astrocytes (large whole-cell capacitance, low input resistance, no sodium current, very negative membrane potential) (for comparison, see Bischofberger et al. 2006). Basic electrophysiological identification and confirmation consisting of subthreshold and suprathreshold voltage commands in the voltage-clamp configuration immediately after break-in was performed on each recording, allowing identification of MFBs also in Cs-based solutions. The holding potential in the voltage-clamp mode was set to -80 $\mathrm{mV}$, if not otherwise stated. Puff application of GABA or muscimol (HEPES-buffered solution) in the CA3 stratum lucidum was performed with a PicoSpritzer III (Parker Instrumentation, Fairfield, NJ) (30-100 $m s$ or $3 \mathrm{~s}$ duration at $14-28 \mathrm{kPa})$. For the reversal potential estimation of the $\mathrm{GABA}_{\mathrm{A}}$ receptor-mediated currents in Figures $2 A$ and $5 C$, the liquid junction potentials were measured for the Cs-based low chloride internal solution $(10 \mathrm{mV})$ and the high chloride internal solution $(4.6 \mathrm{mV}) \mathrm{ac}-$ cording to Neher (1992), and the respective voltage values were corrected post hoc by subtraction of the liquid junction potential from the measured potential. Regression lines from the current-voltage relationships, including the data points from -80 to $+40 \mathrm{mV}$ were calculated, and from those, the reversal potentials were determined. Single-channel recordings of $\mathrm{GABA}_{\mathrm{A}}$ receptors (symmetrical chloride) were either obtained in the whole-cell mode by gently puff-applying muscimol (1-10 $\mu \mathrm{M})$ to the recorded MFB or in the outside-out patch configuration by bath application of $1-10 \mu \mathrm{M}$ GABA; $\mathrm{GABA}_{\mathrm{A}}$ receptor currents in the outside-out patch configuration showed fast rundown, preventing additional detailed analysis. The desensitization properties of presynaptic $\mathrm{GABA}_{\mathrm{A}}$ receptors were studied in the presence of the GABA transporter system 1 (GAT 1) blocker NNC 711 (1,2,5,6-tetrahydro-1-([2(diphenylmethylene)amino]oxy)ethyl]-3-pyridinecarboxylic acid hydrochloride; $1 \mu \mathrm{M}$ ). The mossy fiber input resistance was determined from the voltage response to a $1.25 \mathrm{~s}$ current pulse of $-5 \mathrm{pA}$. For extracellular stimulation in the CA3 stratum radiatum (CA3-SR), a Tungsten bipolar electrode was used. Stimulus intensities ranged from 0.01 to $1 \mathrm{~mA}$ (0.1-0.3 ms pulse duration). All experiments were done at $34 \pm 1{ }^{\circ} \mathrm{C}$.

Drugs. GABA, muscimol, bicuculline, gabazine, NNC 711, CGP 52432, WIN 55,212-2 (R-(+)-[2,3-dihydro-5-methyl-3-(4-morpholinylmethyl)pyrrolo[1,2,3-de]-1,4-benzoxazin-6-yl]-1-naphthalenylmethanone mesylate), AM 251 [ $N$-(piperidin-1-yl)-5-(4-iodophenyl)-1-(2,4dichlorophenyl)-4-methyl-1 $H$-pyrazole-3-carboxamide], and DCG-4 $\left[\left(2 S, 2^{\prime} R, 3^{\prime} R\right)-2-\left(2^{\prime}, 3^{\prime}\right.\right.$-dicarboxycyclopropyl)glycine $]$ were from Tocris (Bristol, UK); glucose was from Merck (Darmstadt, Germany); zolpidem, salts, and other compounds for solutions were from Sigma-Aldrich (Taufkirchen, Germany).

Simulations. Simulations were performed using NEURON (Hines and Carnevale, 1997), version 5.8 for Windows. The granule cell model was taken from Alle and Geiger (2006) using the following passive parameters: axonal membrane resistivity $\left(R_{\mathrm{m}}\right)$ was $60 \mathrm{k} \Omega \cdot \mathrm{cm}^{2}$ (somatodendritic $R_{\mathrm{m}}$ was $\left.40 \mathrm{k} \Omega \cdot \mathrm{cm}^{-2}\right)$, membrane capacitance $\left(C_{\mathrm{m}}\right)$ was 1 $\mu \mathrm{F} \cdot \mathrm{cm}^{-2}$, and plasmic resistivity $\left(R_{\mathrm{i}}\right)$ was $70 \Omega \cdot \mathrm{cm}$. The length of the mossy fiber pearl chain was $3 \mathrm{~mm}$. The resting membrane potential was set to $-78 \mathrm{mV}$. The $\mathrm{GABA}_{\mathrm{A}}$ receptor-mediated maximal conductance of $0.1 \mathrm{nS}$ per MFB used in the simulations was calculated from the upper range of peak current amplitudes of spill-over currents at $-80 \mathrm{mV}$ in ACSF ( $\sim 20 \mathrm{pA}$ at $-80 \mathrm{mV}$, symmetrical chloride) and using a conductance ratio of low versus high intracellular chloride concentration conditions of $\sim 0.5$ at $-80 \mathrm{mV}$ (see Fig. $2 A$ ). GABA $_{\mathrm{A}}$ receptor-mediated conductances were introduced into the axonal membrane in between MFBs at the same density (10 point sources of $0.01 \mathrm{nS}$ distributed along $150 \mu \mathrm{m}$ of axon), because the surfaces of MFBs and interleaved axonal segments in the model are of comparable size. The reversal potential of $\mathrm{GABA}_{\mathrm{A}}$ receptor-mediated currents of $-65 \mathrm{mV}$ is taken to be similar to that of somato-dendritic $\mathrm{GABA}_{\mathrm{A}}$ receptors of granule cells (Misgeld et al., 1986). This would correspond to an intracellular chloride concentration of $\sim 12 \mathrm{~mm}$ for a receptor channel permeable exclusively to chloride ions or $\sim 9 \mathrm{~mm}$, assuming a $\mathrm{HCO}_{3}^{-}$conductance contribution of 0.2 (Bormann et al., 1987) and an intracellular $\left[\mathrm{HCO}_{3}^{-}\right]$of $\sim 16 \mathrm{~mm}$. The reversal potential of $-78 \mathrm{mV}$ was chosen to study isolated shunt effects (corresponding to intracellular chloride concentrations of $\sim 7$ or $\sim 4 \mathrm{mM}$, respectively), and that of $-52 \mathrm{mV}$ (corresponding to $\sim 21$ or $\sim 16 \mathrm{mM}$ intracellular chloride, respectively) was chosen to simulate relatively high presynaptic chloride concentrations as have been observed at the posterior pituitary (Zhang and Jackson, 1993), calyx of Held (Price and Trussell, 2006), and neocortical proximal axons (Szabadics et al., 2006). The time course of the simulated $\mathrm{GABA}_{\mathrm{A}}$ receptor-mediated conduc- 
tance change (see Fig. 6B) was chosen such that the resulting current matched the observed spill-over currents (see Fig. $5 A$ ).

Data analysis. To assess statistical significance, a Wilcoxon signed rank test, a Mann-Whitney $U$ test, or a Kruskal-Wallace test was used. Data are given as mean \pm SEM if not otherwise stated.

\section{Results}

To analyze presynaptic ionotropic $\mathrm{GABA}_{\mathrm{A}}$ receptors, we recorded from MFBs of rat hippocampal slices at $34^{\circ} \mathrm{C}$ (Geiger and Jonas, 2000; Alle and Geiger, 2006).

\section{Functional presynaptic $\mathrm{GABA}_{\mathrm{A}}$ receptors persist into young adulthood}

GABA $(100 \mu \mathrm{M})$ was puff applied $(30-70 \mathrm{~ms})$ to a focalized field including the recorded MFB (Fig. $1 A$ ). Using symmetrical chloride conditions, GABA application evoked transient inward currents (at $-80 \mathrm{mV} ; n=50)$. GABA-evoked currents had an apparent rise time $(20-80 \%)$ and decay time constant of $\sim 25$ and $150 \mathrm{~ms}$, respectively. However, this time course reflects not only gating properties of the receptors but also the speed limitations of the drug application and the diffusion and uptake of GABA. GABA-evoked currents were reversibly blocked by the competitive $\mathrm{GABA}_{\mathrm{A}}$ receptor antagonist bicuculline $(10 \mu \mathrm{M})$ to $0.07 \pm$ 0.02 of the baseline peak current amplitude $(p<0.05 ; n=4)$ (Fig. $1 B$ ). The mean peak current amplitude was primarily independent of the ages of animals, which ranged from $12 \mathrm{~d}$ to 3 months ( $p>0.4 ; 12$ - to 14 -d-old animals: $140 \pm 44 \mathrm{pA}, n=7 ; 3$ to 4 -week-old animals: $86 \pm 7 \mathrm{pA}, n=36$; 3 -month-old animals: $75 \pm 7 \mathrm{pA}, n=7$ ) (Fig. 1C). This indicates that the presence of presynaptic $\mathrm{GABA}_{\mathrm{A}}$ receptors in hippocampal mossy fibers is preserved during development, which is in marked contrast to the early developmental downregulation of presynaptic $\mathrm{GABA}_{\mathrm{A}}$ receptors found at the calyx of Held (Turecek and Trussell, 2002).

\section{$\mathrm{GABA}_{\mathrm{A}}$ receptor-mediated currents are generated on the mossy fiber}

To analyze the permeation properties of presynaptic $\mathrm{GABA}_{\mathrm{A}}$ receptors, we performed current-voltage relationships for two different intracellular chloride concentrations. The reversal potential of evoked currents in response to the $\mathrm{GABA}_{\mathrm{A}}$ receptor agonist muscimol $(30 \mu \mathrm{M})$ shifted from $-68 \mathrm{mV}(10 \mathrm{mM}$ intracellular chloride concentration; $n=5 \mathrm{MFBs}$ ) to $+4.8 \mathrm{mV}$ (134 mM intracellular chloride concentration; $n=5 \mathrm{MFBs}$ ) (Fig. 2A), indicating that presynaptic $\mathrm{GABA}_{\mathrm{A}}$ receptors represent chloridepermeable channels. For the low internal chloride concentration, the measured reversal potential was very close to the calculated Nernst potential of a receptor channel conducting exclusively chloride ions $(-69 \mathrm{mV})$. This indicated a negligible conductance contribution from $\mathrm{HCO}_{3}^{-}$under our experimental conditions, similar to a very recent study at the calyx of Held (Price and Trussell, 2006). A contribution of $\mathrm{GABA}_{\mathrm{C}}$ receptors to the muscimol-evoked currents was unlikely, because GABA-evoked currents were blocked by bicuculline (Fig. 1A) (Sieghart, 1995). Single-channel currents of presynaptic $\mathrm{GABA}_{\mathrm{A}}$ receptors recorded in symmetrical chloride either in the whole-cell configuration (Fig. $2 B$ ) or from MFB outside-out patches (Fig. $2 C$ ) had a mean amplitude of $2.9 \pm 0.16 \mathrm{pA}$ at $-80 \mathrm{mV}(n=5 \mathrm{MFBs})$, corresponding to a single-channel conductance of $36 \mathrm{pS}$ similar to a main conductance state of $\mathrm{GABA}_{\mathrm{A}}$ receptors found in other preparations (Jones and Westbrook, 1995; Turecek and Trussell, 2002).
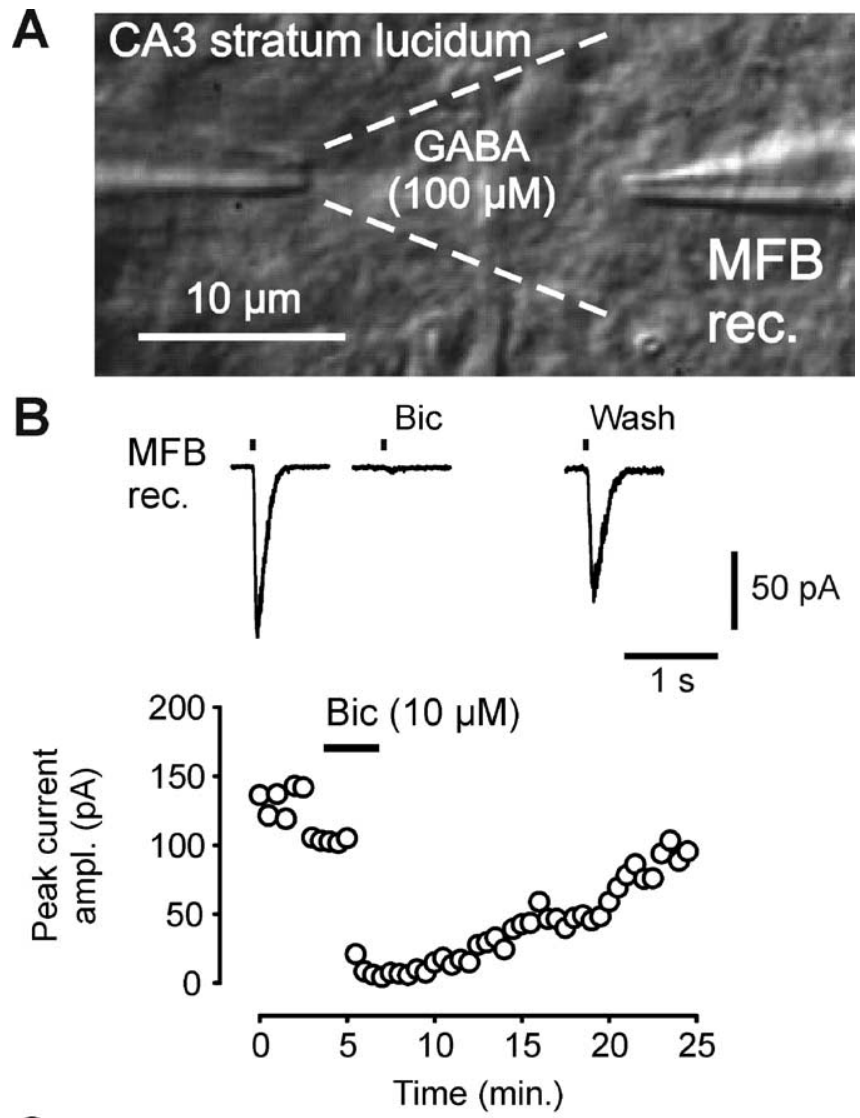

C

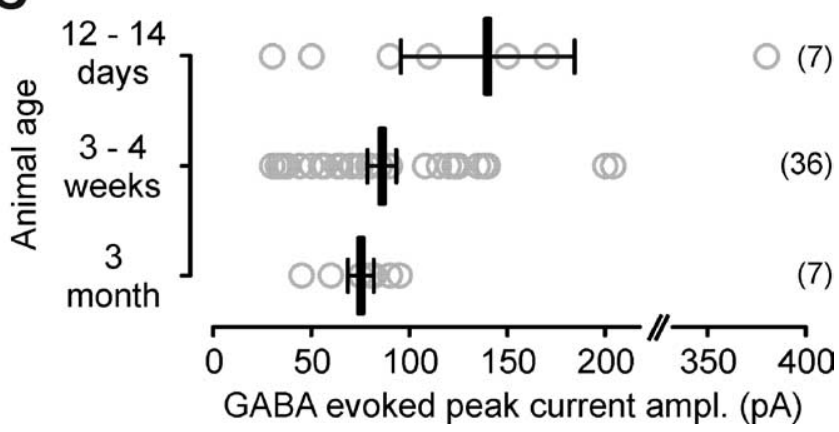

Figure 1. GABA-evoked currents in hippocampal mossy fibers. $\boldsymbol{A}$, The stimulation and recording (rec.) configuration. Direct presynaptic recordings from MFBs at $34^{\circ} \mathrm{C}$ and focal puff application of GABA through a second glass pipette are shown. $\boldsymbol{B}$, Top, Average traces of GABAevoked presynaptic inward currents (symmetrical chloride condition) and bath application of the $G_{A B A_{A}}$ receptor antagonist bicuculline (Bic). Ticks indicate puff application. Bottom, Peak current amplitude plotted over recording time. C, GABA-evoked peak current amplitudes in mossy fibers of animals aged between $12 \mathrm{~d}$ and 3 months. rec., Recording; ampl., amplitude.

Presynaptic $\alpha_{2}$-subunit containing $\mathrm{GABA}_{\mathrm{A}}$ receptors show a low GABA affinity

Presynaptic $\mathrm{GABA}_{\mathrm{A}}$ receptors desensitize during prolonged exposure to GABA (Jones and Westbrook, 1995) in a concentration-dependent manner (Berger et al., 1998). GABA puff application for $3 \mathrm{~s}$ at concentrations of 10 and $100 \mu \mathrm{M}(n=$ 3 and 8 , respectively) caused a marked reduction (Fig. $3 A$ ) of the evoked current in the late application phase; the apparent desensitization decay time constant tended to be larger at the lower agonist concentration $(1.2 \pm 0.2 \mathrm{~s}$ for $10 \mu \mathrm{M}$ GABA vs $0.8 \pm 0.1 \mathrm{~s}$ for $100 \mu \mathrm{M})$. The GABA dose-response curve of presynaptic $\mathrm{GABA}_{\mathrm{A}}$ receptor-mediated peak current amplitudes yielded an apparent $\mathrm{EC}_{50}$ of $\sim 60 \mu \mathrm{M}$ (Fig. $3 B$ ) indicating a rather low affinity for GABA (Galaretta and Hestrin, 1997; Berger et al., 1998). 


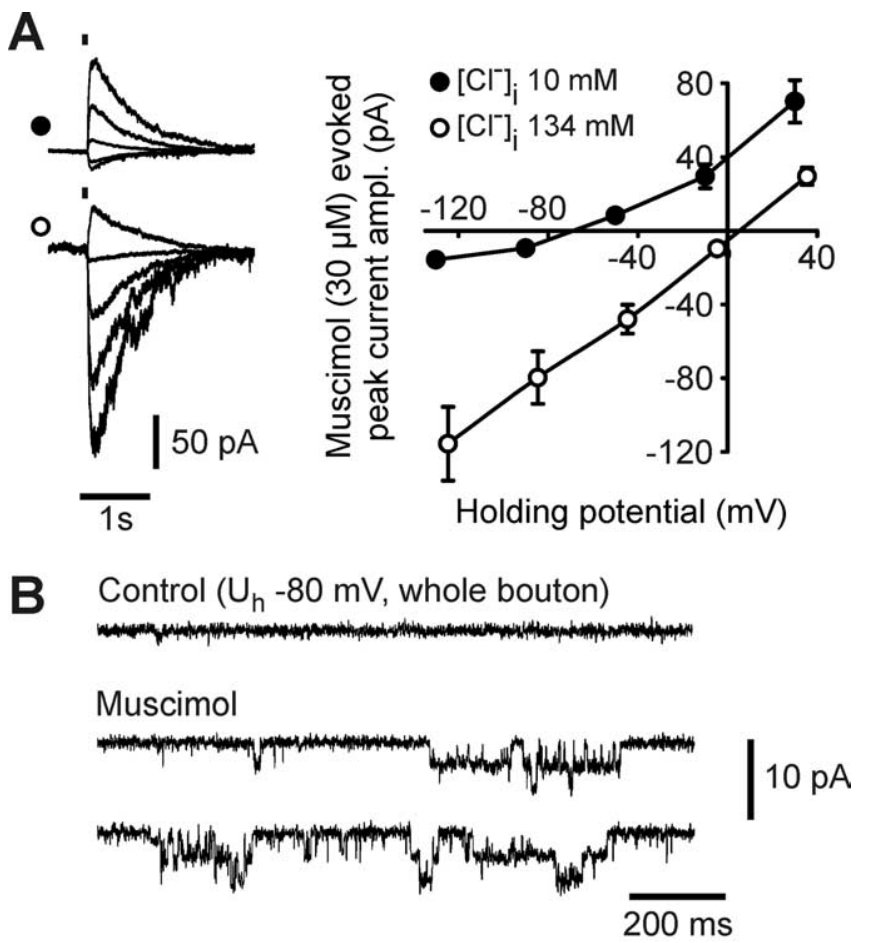

C Control $\left(\mathrm{U}_{\mathrm{h}}-80 \mathrm{mV}\right.$, outside-out patch)

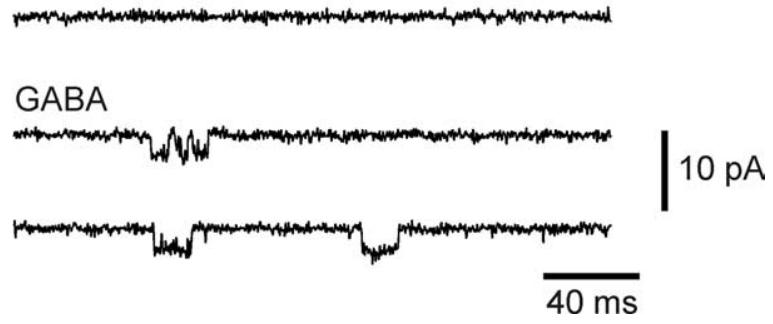

Figure 2. $G A B A_{A}$ receptor-mediated currents are generated on the mossy fiber. $A$, Left, Muscimol-evoked currents recorded with a low (top trace) and a high (bottom trace) intracellular chloride concentration at different presynaptic holding potentials. Right, Muscimolevoked currents plotted over the presynaptic holding potential for the low (filled symbols) and the high (open symbols) intracellular chloride condition (each $n=5$ ). ampl., Amplitude. B, MFB recording in the whole-cell configuration before and during focal application of muscimol to the $M F B$ via a second pipette. $C$, Recording from an outside-out patch of an MFB before and during bath application of GABA.

Finally, to test for the possible subunit composition of these receptors, we bath applied zolpidem, a benzodiazepine binding site agonist with high selectivity for the $\alpha_{1}$-subunit over $\alpha_{2}$ - and $\alpha_{3}$-subunits, at $0.02,0.2$, and $2 \mu \mathrm{M}$ for two different GABA concentrations (each $n=4$ ). Consistent with $\mathrm{GABA}_{\mathrm{A}}$ receptors that contain $\alpha_{2}$ - or $\alpha_{3}$-subunits, zolpidem further potentiated the GABA puff-evoked charge transfer beyond a concentration of 0.2 $\mu \mathrm{M}(p<0.02$ for comparison of $0.2 \mathrm{vs} 2 \mu \mathrm{M}$ zolpidem at 10 and $100 \mu \mathrm{M}$ GABA application, respectively) (Fig. 3C). This is not to be expected for $\mathrm{GABA}_{\mathrm{A}}$ receptors containing predominantly $\alpha_{1^{-}}$ subunits, which show saturation of the potentiating effect of zolpidem at a concentration of $0.2 \mu \mathrm{M}$ (Sieghart, 1995). However, these results are in line with previous immunohistochemical evidence for the presence of $\alpha_{2}$-subunit-containing receptors in rat hippocampal mossy fibers (Ruiz et al., 2003). A major contribution of $\mathrm{GABA}_{\mathrm{A}}$ receptors containing $\alpha_{3}$-subunits is unlikely because this subunit is scarcely expressed in the hippocampus (Sperk et al., 1997).
A
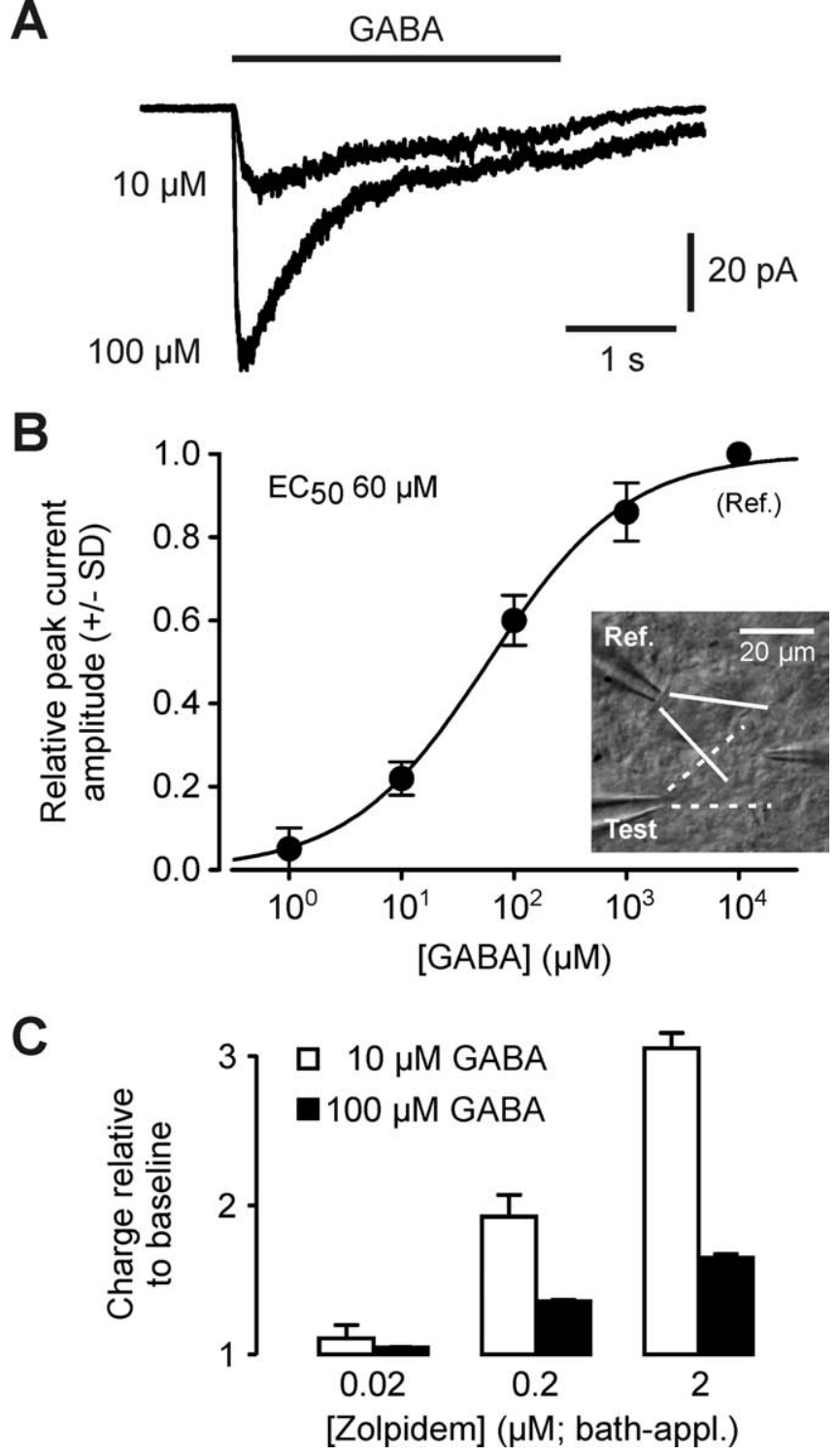

Figure 3. Basic characterization of presynaptic $G A B A_{A}$ receptors on mossy fibers. $A$, Focal application of GABA for $3 \mathrm{~s}$ at two different GABA concentrations. $B$, Dose-response curve for $G A B A$ applied to presynaptic $G A B A_{A}$ receptors. The peak current amplitude of puff-evoked currents normalized to that evoked with $10 \mathrm{~mm}$ GABA (Ref.) is plotted over the respective GABA "test" concentration (Test; $n=3$ for each test concentration). Test and Ref. were applied interleaved by two pipettes (see inset). $C$, The benzodiazepine binding site agonist zolpidem was bath applied (bath-appl.) at increasing concentrations during GABA puff application with 10 and $100 \mu \mathrm{M}$ GABA (each $n=4)$.

Tonic activation of presynaptic $\mathrm{GABA}_{\mathrm{A}}$ receptors is prevented by the GAT 1

As a consequence of the pharmacological properties of presynaptic $\mathrm{GABA}_{\mathrm{A}}$ receptors, their activation required relatively high GABA concentrations. To test whether tonic activation of presynaptic $\mathrm{GABA}_{\mathrm{A}}$ receptors contributed to membrane resistivity, we monitored the mossy fiber input resistance while bathapplying bicuculline (10 $\mu \mathrm{M})$ (Fig. $4 \mathrm{~A})$. The input resistance did not increase significantly in the presence of the $\mathrm{GABA}_{\mathrm{A}}$ receptor antagonist (1.01 \pm 0.05 relative to baseline; $p>0.5 ; n=5)$, indicating that the ambient GABA concentration is not high enough to activate presynaptic $\mathrm{GABA}_{\mathrm{A}}$ receptors. Consistently, it was reported in the hippocampal CA1 area (Isaacson et al., 1993; Frahm et al., 2001) that the extracellular GABA concentration is 
A

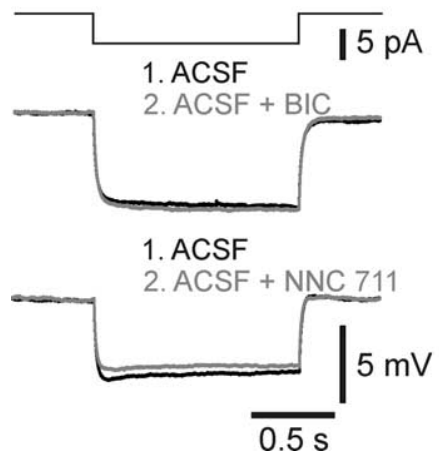

B

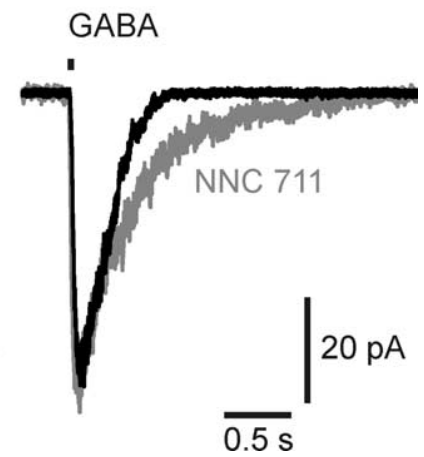

Figure 4. Tonic activation of presynaptic $\mathrm{GABA}_{A}$ receptors is prevented by GAT 1. A, Mossy fiber input resistance was monitored using a long hyperpolarizing current pulse (top) and recording the resulting voltage traces (bottom) during perfusion with ACSF (baseline condition; black traces) and with either $10 \mu \mathrm{m}$ bicuculline (BIC; middle, gray trace) or $1 \mu \mathrm{M}$ NNC 711 (bottom, gray trace) added to the ACSF. B, Bath application of the GAT 1 blocker (NNC 711, 1 $\mu \mathrm{M})$ during puff application of GABA to an MFB. Current traces are shown superimposed.

tightly controlled by GAT 1 . To address whether this also applies to the CA3 region, we bath applied NNC 711, a GAT 1 blocker (1 $\mu \mathrm{M})$. Mossy fiber input resistance decreased significantly to $0.91 \pm 0.01$ of baseline $(n=4 ; p<0.05)$ (Fig. $4 A)$, indicating that GABA uptake prevents activation of presynaptic $\mathrm{GABA}_{\mathrm{A}}$ receptors by ambient GABA. Furthermore, during puff applications of GABA to MFBs, NNC 711 did not affect the peak current amplitude of evoked currents ( $p>0.5 ; n=5$ ) (Fig. $4 B$ ) but significantly increased the decay time constant of the current (to $2.5 \pm$ 0.1 of baseline; $p<0.05 ; n=5$ ), demonstrating the tight control of transient $\mathrm{GABA}_{\mathrm{A}}$ receptor-mediated currents by GAT 1 . Together, the ambient GABA concentration was too low to activate presynaptic $\mathrm{GABA}_{\mathrm{A}}$ receptors tonically.

\section{Transient, presynaptic $\mathrm{GABA}_{\mathrm{A}}$ receptor-mediated spill-over currents}

This raised the question whether presynaptic ionotropic $\mathrm{GABA}_{\mathrm{A}}$ receptors can be activated by AP-evoked synaptic GABA release. Extracellular high-frequency stimulation $(20$ pulses at $100 \mathrm{~Hz})$ in CA3-SR resulted in a transient current that decayed rapidly at the end of the stimulation (Fig. 5A). The peak current amplitude could be potentiated by application of zolpidem (to $1.85 \pm 0.15$ of baseline; $n=2$ ) and by blocking GAT 1 (to $2.48 \pm 0.5$ of baseline; $p<0.05 ; n=5$ ) (Fig. $5 A, B)$. Gabazine $(3-10 \mu \mathrm{M}$ ), a specific $\mathrm{GABA}_{\mathrm{A}}$ receptor antagonist, reduced the stimulated currents to $0.07 \pm 0.03$ of baseline $(p<0.05 ; n=7)$ (Fig. $5 A, B$ ), similar to the block of puff-evoked currents by bicuculline. Stimulation at a lower frequency $(30 \mathrm{~Hz})$ resulted in markedly smaller spill-over peak current amplitudes (Fig. 5B). The recorded GABA spill-over currents exhibited a linear current-voltage relationship (symmetrical chloride condition) reversing at $-1.3 \mathrm{mV}(n=3)$ (Fig. 5C), indicating sufficient voltage control over the site of current generation. On an elongated, thin structure like a mossy fiber, this in turn implies that the current generation site was rather close to the recording site. Together, these results indicate that the extracellularly stimulated currents were generated by GABA spill-over and subsequent activation of presynaptic $\mathrm{GABA}_{\mathrm{A}}$ receptors containing the $\alpha 2$-subunit.

\section{GABA spill-over currents are sensitive to cannabinoid 1} receptor activation

Prime candidates for the GABA source leading to spill-over currents are the mossy fiber-associated interneurons (Vida and

A CA3-SR stim.
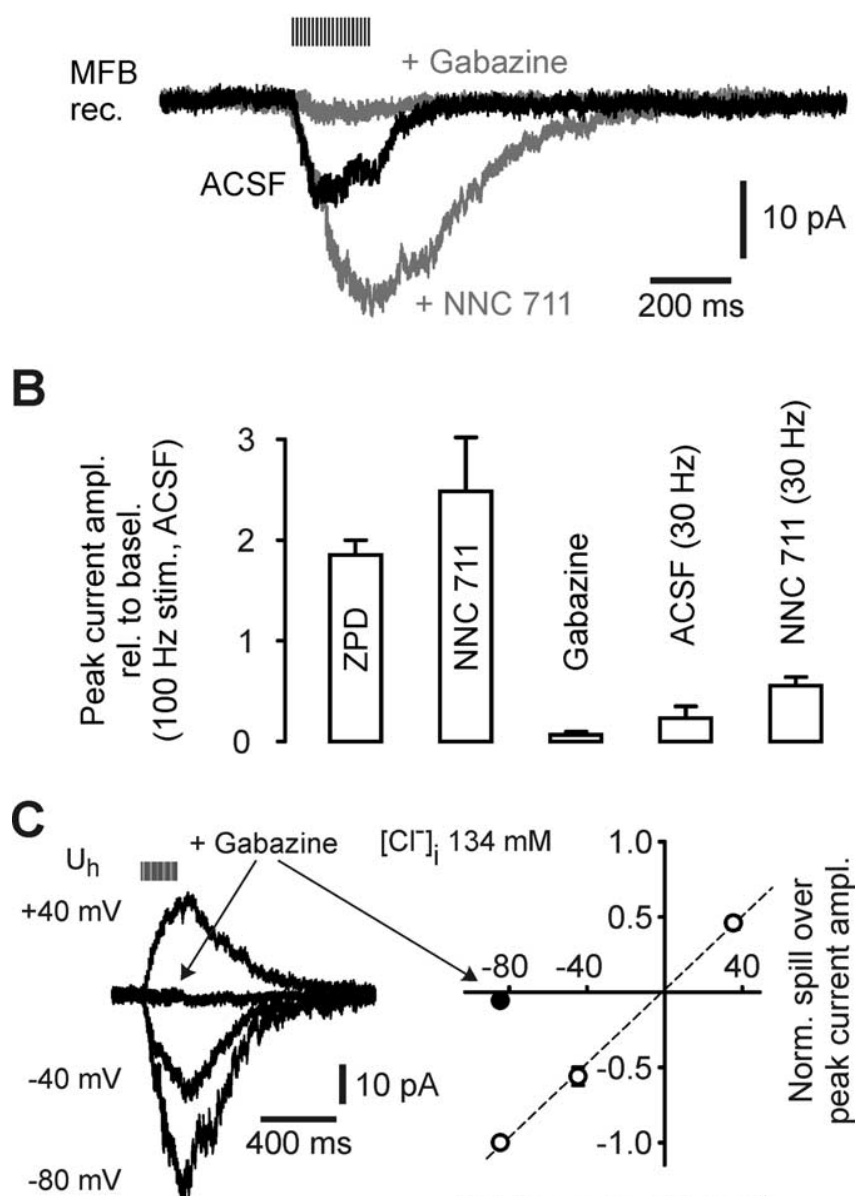

Holding potential (mV)

Figure 5. High-frequency stimulation in CA3-SR elicits transient $G A B A_{A}$ receptor-mediated spill-over currents in MFBs. $A$, Twenty pulses at $100 \mathrm{~Hz}$ applied to the CA3-SR. Gray traces, Successive bath application of the GAT 1 blocker NNC $711(1 \mu \mathrm{M})$ and the GABA $A_{A}$ receptor antagonist gabazine $(10 \mu \mathrm{M})$. rec., Recording. $B$, Bar graph summarizing the effect of bath application of zolpidem (ZPD; $2 \mu \mathrm{m} ; n=2)$, NNC $711(1 \mu \mathrm{m} ; n=5)$, and gabazine (3-10 $\mu \mathrm{m}$; $n=7)$ to the peak current amplitude of spill-over currents and the effect of lowered stimulation frequency ( $30 \mathrm{~Hz}$ ) in ACSF and NNC $711(n=3)$. rel., Relative, basel., baseline. C, Left, Spill-over currents recorded at different presynaptic holding potentials $\left(U_{h}\right)$. Right, Normalized (Norm.) spill-over peak current amplitude (open symbols) plotted over the presynaptic holding potential. The filled symbol indicates the effect of gabazine application (10 $\mu \mathrm{M})$. stim., Stimulation; ampl., amplitude.

Frotscher, 2000). Their dendrites extend into CA3-SR, their axons are coaligned with the mossy fibers (Tóth and McBain, 1998; Vida and Frotscher, 2000; Losonczy et al., 2004), and their GABAergic terminals are in close apposition to MFBs, as revealed by electron microscopy (Vida and Frotscher, 2000). The GABA release from their presynaptic terminals requires high-frequency stimulation and is under control of the cannabinoid 1 (CB1) receptor (Katona et al., 1999; Losonczy et al., 2004). Therefore, we tested whether spill-over currents were sensitive to the CB1 receptor agonist WIN 55,212-2. Bath application of WIN $55,212-2(2 \mu \mathrm{M})$ significantly reduced $\mathrm{GABA}_{\mathrm{A}}$ receptor mediated spill-over peak current amplitudes to $0.66 \pm 0.02$ of baseline $(p<0.05 ; n=4)$ (Fig. 6A-C). Successive bath application of the $\mathrm{CB} 1$ receptor antagonist AM $251(10 \mu \mathrm{M})$ reversed the reduction into a slight increase in the spill-over current to $1.12 \pm 0.02$ of baseline $(p<0.05 ; n=4)$ (Fig. $6 A-C)$. However, because a substantial part of the GABA spill-over current remained in the 
A CA3-SR stim.

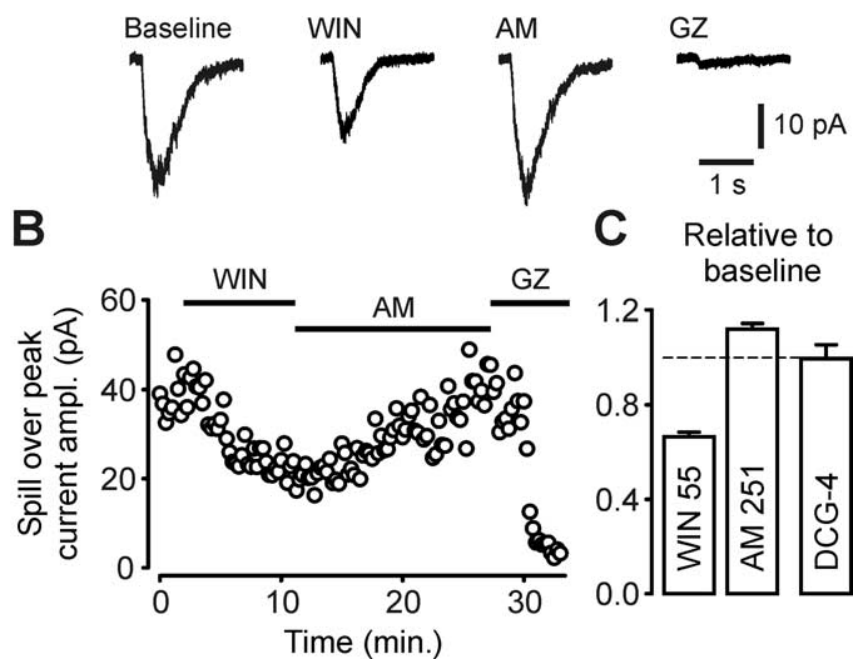

Figure 6. Presynaptic GABA spill-over is sensitive to $C B 1$ receptor activation. $A$, Averaged spill-over currents recorded at an MFB. Pharmacological conditions are indicated above the traces. stim., Stimulation. B, Spill-over peak current amplitude (ampl.) is plotted over the recording time. Horizontal bars indicate application of (B1 receptor agonist WIN 55,212-2 (2 $\mu \mathrm{M})$, CB1 receptor antagonist AM $251(10 \mu \mathrm{M})$, and gabazine $(10 \mu \mathrm{M})$. C, Summary bar graph of experiments shown in $\boldsymbol{B}(n=4)$ and of experiments in which the group 2 metabotropic glutamate receptor agonist DCG-4 $(1 \mu \mathrm{m})$ was bath applied $(n=4)$. Experiments were done in the presence of $2 \mu \mathrm{M}$ zolpidem and $1 \mu \mathrm{M}$ NNC 711. WIN, WIN 55,212-2; AM, AM 251; GZ, gabazine.

presence of WIN 55,212-2, we cannot exclude a partial contribution from interneurons not expressing presynaptic CB1 receptors. In contrast, the group 2 metabotropic glutamate receptor agonist DCG-4 did not change the spill-over current significantly $(1.0 \pm 0.06$ of baseline; $p>0.5 ; n=4)$ (Fig. $6 C$ ), indicating that GABA release from neighboring MFBs did not contribute to the recorded presynaptic $\mathrm{GABA}_{\mathrm{A}}$ receptor-mediated spill-over currents.

\section{Simulations of activating presynaptic $\mathrm{GABA}_{\mathrm{A}}$ receptors on single and multiple MFBs including axonal segments}

The presynaptic $\mathrm{GABA}_{\mathrm{A}}$ receptor-mediated conductances activated by physiological stimuli were quite small ( $0.2 \mathrm{nS}$ per MFB including adjacent axon parts), raising the question of which function presynaptic $\mathrm{GABA}_{\mathrm{A}}$ receptor-mediated signaling may serve? The effect of $\mathrm{GABA}_{\mathrm{A}}$ receptor activation on membrane potential depends on the resting membrane potential, membrane resistivity, and the intracellular chloride concentration. To explore possible consequences of transient presynaptic $\mathrm{GABA}_{\mathrm{A}}$ receptor activation, we incorporated $\mathrm{GABA}_{\mathrm{A}}$ receptor-mediated conductances with experimentally observed magnitudes into a constrained granule cell model (see Materials and Methods) (Alle and Geiger, 2006). Because the axons of mossy fiber-associated interneurons, which represent the most likely GABA source, are coaligned with mossy fibers (Fig. 7A) (Vida and Frotscher, 2000), we simulated activation of presynaptic $\mathrm{GABA}_{\mathrm{A}}$ receptors on a single MFB and on multiple MFBs (Fig. 7B,C) (Jackson and Zhang, 1995). Three different $\mathrm{GABA}_{\mathrm{A}}$ receptor reversal potentials were compared: the reversal potential was set (1) to the resting membrane potential ( $-78 \mathrm{mV}$ ) (Alle and Geiger, 2006), (2) to that found at the granule cell soma $(-65 \mathrm{mV})$ (Misgeld et al., 1986 ), and (3) to that found in axons and presynaptic elements of other brain regions $(-52 \mathrm{mV}$ ) (Zhang and Jackson, 1993; Price and Trussell, 2006; Szabadics et al., 2006). Activation of presynaptic $\mathrm{GABA}_{\mathrm{A}}$ receptors on a single $\mathrm{MFB}$ resulted in considerable

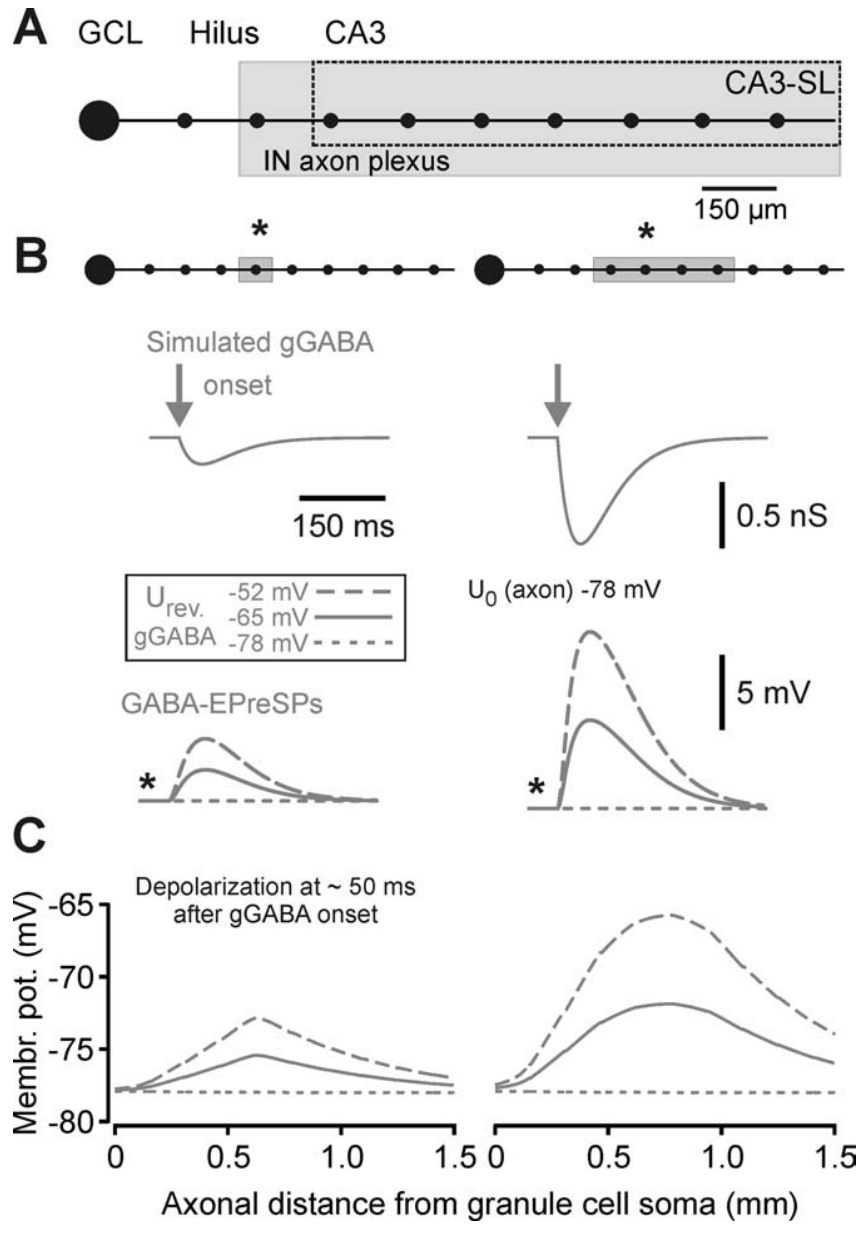

Figure 7. Simulations of activating presynaptic $G A B A_{A}$ receptors on single and multiple MFBs including axonal segments. $A$, Scheme illustrating the spatial relationship of mossy fibers (pearl chain) and the axonal arborization (gray shaded area) of mossy fiber-associated interneurons (IN) (Vida and Frotscher, 2000) in CA3 stratum lucidum (CA3-SL). GCL, Granule cell layer. $\boldsymbol{B}$, Top, Scheme indicating activation of presynaptic $G_{A B} A_{A}$ receptors (gray box) on a single MFB including $75 \mu \mathrm{m}$ of mossy fiber in both directions (left) or on four MFBs including corresponding axonal segments (right). Middle, Corresponding simulated presynaptic $G_{A B A_{A}}$ receptor-mediated conductance $\left(g G A B A_{A}\right)$ changes. Bottom, GABA-EPreSPs. The asterisks indicate the MFB from which GABA-EPreSP is shown. Three different reversal potentials of the $G A B A_{A}$ receptor-mediated current were assumed (see inset). $U_{\text {rev }}$ Reversal potential; $U_{0}$, resting potential. C, Corresponding maximal axonal membrane depolarizations (at $\sim 50 \mathrm{~ms}$ after the onset of $g G A B A$ ) plotted over the axonal distance from the granule cell soma. The line code corresponds to the inset in $\boldsymbol{B}$. Membr. pot., Membrane potential.

membrane potential depolarizations for conditions 2 and 3 (Fig. $7 B$ ), and simultaneous activation of $\mathrm{GABA}_{\mathrm{A}}$ receptors on multiple MFBs resulted in stronger depolarizations because of the electrotonic compactness of the mossy fiber (Fig. $7 B, C$ ). Thus, the simulations suggest that $\mathrm{GABA}_{\mathrm{A}}$ receptor-mediated presynaptic spill-over currents are able to induce transient depolarizations similar to excitatory presynaptic potentials (EPreSPs) during axonal propagation of subthreshold dendritic signals, which have been shown to enhance AP-evoked transmitter release (Alle and Geiger, 2006; Shu et al., 2006).

\section{Discussion}

In summary, we report direct recordings of presynaptic $\mathrm{GABA}_{\mathrm{A}}$ receptor-mediated currents at a glutamatergic synapse in the hippocampal cortex. We show that GABAergic transmission onto presynaptic terminals of the hippocampal mossy fiber system proceeds by spill-over of GABA released during high-frequency 
firing of CB1 receptor-expressing interneurons. The presynaptic spill-over currents are mediated by $\alpha_{2}$-subunit-containing, lowaffinity $\mathrm{GABA}_{\mathrm{A}}$ receptors and exhibit a transient time course that is tightly controlled by GABA uptake mechanisms. In contrast to a previous study, tonic presynaptic $\mathrm{GABA}_{\mathrm{A}}$ receptor activation was not observed (Ruiz et al., 2003). Simulations show that experimentally determined, presynaptic $\mathrm{GABA}_{\mathrm{A}}$ receptormediated conductances contribute substantially to subthreshold electrical signaling in hippocampal mossy fibers.

\section{Developmental stability of $\mathrm{GABA}_{\mathrm{A}}$ receptor expression}

Most studies at central glutamatergic synapses have been performed using tissue from rather immature animals (Turecek and Trussell, 2001; Jang et al., 2005, 2006). At the calyx of Held, presynaptic $\mathrm{GABA}_{\mathrm{A}}$ receptor expression is downregulated during early development (Turecek and Trussell, 2002). In contrast, we found that $\mathrm{GABA}_{\mathrm{A}}$ receptor expression is primarily unaltered during development and persists into adulthood (Fig. 1). The mean $\mathrm{GABA}_{\mathrm{A}}$ receptor-mediated current amplitude in adult animals translates into a conductance density of $0.65 \mathrm{mS} \cdot \mathrm{cm}^{-2}$ (assuming a MFB surface of $\sim 150 \mu \mathrm{m}^{2}$ ) (Alle and Geiger, 2006) that is slightly larger than the $\mathrm{GABA}_{\mathrm{A}}$ receptor-mediated conductance density found at the calyx of Held from newborn animals $\left(0.44 \mathrm{mS} \cdot \mathrm{cm}^{-2}=11 \mathrm{nS} / 2500 \mu \mathrm{m}^{2}\right.$ ) (Sätzler et al., 2002; Turecek and Trussell, 2002) and the peptidergic terminals in the posterior pituitary of juvenile animals $\left(0.38 \mathrm{mS} \cdot \mathrm{cm}^{-2}\right)$ (Zhang and Jackson, 1995). These presynaptic $\mathrm{GABA}_{\mathrm{A}}$ receptor-mediated conductance densities are found to be $\sim 100$-fold smaller than the mixed densities of somatic synaptic and extrasynaptic $\mathrm{GABA}_{\mathrm{A}}$ receptors of hippocampal granule cells, which give rise to the mossy fibers $\left(46 \pm 3.5 \mathrm{mS} \cdot \mathrm{cm}^{-2} ; n=3\right.$ nucleated patches; data not shown), dentate gyrus basket cells (Berger et al., 1998) $(\sim 33$ $\mathrm{mS} \cdot \mathrm{cm}^{-2}$ ), or CA1 pyramidal neurons (Banks and Pearce, 2000) $\left(\sim 60 \mathrm{mS} \cdot \mathrm{cm}^{-2}\right)$.

GABA puff-evoked peak current amplitudes in MFBs using $100 \mu \mathrm{M}$ GABA (Fig. $1 C$ ) divided by the mean single-channel current at the same holding potential (2.9 pA) (Fig. $2 B$ ) yield 10-70 $\mathrm{GABA}_{\mathrm{A}}$ receptors per MFB. Considering, in addition, the doseresponse relationship for GABA (Fig. $3 B$ ) and a maximal $\mathrm{GABA}_{\mathrm{A}}$ receptor channel open probability of $0.6-0.8$ at the peak of the current (Jones and Westbrook, 1995), we estimate that the number of $\mathrm{GABA}_{\mathrm{A}}$ receptors per MFB may vary between 20 and 200. However, this number is still one to two orders of magnitude lower than that of major channel proteins in MFBs, such as sodium channels (2000 per MFB) (Engel and Jonas, 2005) and voltage-gated calcium channels (1200 per MFB) (Bischofberger et al., 2002).

\section{Presynaptic $\mathrm{GABA}_{\mathrm{A}}$ receptor-mediated signaling is transient}

The transient nature of presynaptic $\mathrm{GABA}_{\mathrm{A}}$ receptor-mediated signaling in our study is in contrast to the findings of a recent study using slices from guinea pigs demonstrating a large tonic activation (Ruiz et al., 2003). This difference could be explained by a species-specific difference in hippocampal GABA signaling (Walker et al., 2001; Gutiérrez, 2003), a lower recording temperature (Ruiz et al., 2003) that markedly reduces transmitter uptake by transporters (Mitchell and Silver, 2000; Binda et al., 2002), and a possible contribution of GABA receptors in the surrounding tissue to the observed effects, as discussed in Ruiz et al. (2003). However, in accordance with that study, we found that presynaptic $\mathrm{GABA}_{\mathrm{A}}$ receptors in rat mossy fibers contain the $\alpha_{2}$-subunit.

The observed absence of tonic activation in hippocampal mossy fibers is consistent with the functional and pharmacological properties of presynaptic $\mathrm{GABA}_{\mathrm{A}}$ receptors. Their low affinity for GABA in combination with GABA uptake mechanisms, such as GAT 1, prevents tonic activation in presynaptic elements. Similar observations have been reported for CA1 pyramidal neuron dendrites (Isaacson et al., 1993; Frahm et al., 2001). Furthermore, the lack of tonic activation is in accordance with the absent expression of high-affinity $\delta$-subunit-containing extrasynaptic $\mathrm{GABA}_{\mathrm{A}}$ receptors in hippocampal mossy fibers (Sperk et al., 1997; Wei et al., 2003) but is in contrast to the tonic activation found at the somato-dendritic domain of dentate gyrus granule cells, in which $\delta$-subunit- containing receptors are expressed (Sperk et al., 1997; Nusser and Mody, 2002; Wei et al.; 2003; Farrant and Nusser, 2005), demonstrating functional differentiation between cellular compartments.

\section{Functional relevance of transient GABAergic spill-over transmission}

Several studies indicate that axonal $\mathrm{GABA}_{\mathrm{A}}$ receptor activation leads to a pronounced depolarization (Zhang and Jackson, 1993; Ruiz et al., 2003; Jang et al., 2006; Szabadics et al., 2006), presumably because of high presynaptic chloride concentrations $(\sim 20$ mm) (Zhang and Jackson, 1993; Turecek and Trussell, 2001; Price and Trussell, 2006). Specifically, a depolarizing effect in mossy fibers was reported recently (Ruiz et al., 2003; Jang et al., 2006). Consistently, important chloride extrusion mechanisms, such as the neuron-specific $\mathrm{K}-\mathrm{Cl}$ cotransporter (KCC2), do not seem to be expressed in mossy fibers (Gulyás et al., 2001). In addition, the intracellular chloride concentration in mossy fibers may be subject to activity-dependent regulation, as has been shown in other neuronal compartments (Fiumelli et al., 2005).

In the posterior pituitary and the spinal cord, presynaptic $\mathrm{GABA}_{\mathrm{A}}$ receptor-mediated inhibition of transmitter release seemed mainly to be caused by changes in the presynaptic AP because of sodium channel inactivation caused by $\mathrm{GABA}_{\mathrm{A}}$ receptor-mediated depolarization (Eccles et al., 1963; Zhang and Jackson, 1993). At the calyx of Held, presynaptic activation of $\mathrm{GABA}_{\mathrm{A}}$ receptors or glycine receptors caused a facilitation of $\mathrm{AP}$-dependent transmitter release, although the chloride concentration in the calyx of Held was found to be similar to that in the peptidergic terminals of the posterior pituitary (Zhang and Jackson, 1993; Price and Trussell, 2006). Steady-state depolarization at the calyx of Held by $\sim 10 \mathrm{mV}$ causes only little AP attenuation but a rise of resting calcium concentration (Awatramani et al., 2005). Steady-state depolarization of mossy fibers by elevating the extracellular potassium to increasing concentrations lead to a bidirectional modulation of transmitter release at the mossy fiber-CA3 synapse (Schmitz et al., 2001). Similar to the calyx of Held, mild potassium elevation causing a facilitation of transmitter release corresponds to a steady-state depolarization of $\sim 10$ $\mathrm{mV}$ in mossy fibers that does not cause considerable changes in AP shape or amplitude (Alle and Geiger, 2006). However, at more pronounced depolarization, mossy fiber APs become markedly attenuated (Alle and Geiger, 2006) corresponding to a depression of transmitter release (Schmitz et al., 2001). In addition, mossy fibers express voltage-gated potassium channels, which generate a large steady-state window conductance well below firing threshold (Geiger and Jonas, 2000). Thus, at depolarizing potentials, mossy fibers exhibit an increasingly higher input conductance (Alle and Geiger, 2006) that uncouples subthreshold signaling between granule cell soma and MFBs. Intermediate depolarizations would facilitate transmitter release consistent with the facilitation of transmitter release of a recent study (Jang 
et al., 2006), whereas marked depolarization requiring high intracellular chloride concentrations could lead to inhibition. Ongoing activation of presynaptic $\mathrm{GABA}_{\mathrm{A}}$ receptors might contribute to an activity-dependent increase in the intracellular chloride concentration considering the small surface-to-volume ratio of axon and presynaptic elements. Whether ongoing highfrequency interneuron firing occurs in vivo that would generate lasting presynaptic $\mathrm{GABA}_{\mathrm{A}}$ receptor activation remains to be addressed.

In our simulations, we focused on the effects of transient GABA spill-over-activated conductance changes that we observed experimentally. Because of the negative resting membrane potential and the electrotonic compactness of mossy fibers (Alle and Geiger, 2006), GABA spill-over-activated conductances are able to generate EPreSPs in the axon and presynaptic elements similar in amplitude and shape to those generated by axonal propagation of dendritic EPSPs (Alle and Geiger, 2006; Shu et al., 2006), if depolarizing intracellular chloride concentrations are assumed. These GABA-EPreSPs, although generated locally in the CA3 region, significantly depolarize neighboring MFBs, favoring substantial integration of GABAergic signaling along the axon. In contrast, it does not seem very likely that GABAEPreSPs contribute to independent modulation of individual MFBs (Fig. 7C).

Similarly to propagated EPreSPs, locally generated transient GABA-EPreSPs are not assumed to interact with the shape of APs (Alle and Geiger, 2006). Thus, like propagated EPreSPs, transient GABA-EPreSPs per se will enhance transmitter release (Alle and Geiger, 2006). The relative contributions of concomitant activation of presynaptic $\mathrm{GABA}_{\mathrm{A}}$ receptors, $\mathrm{GABA}_{\mathrm{B}}$ receptors (Vogt and Nicoll, 1999; Kulik et al., 2003), and postsynaptic GABA $_{A}$ receptors to the modulation of information transfer at the mossy fiber-CA3 remain to be deciphered.

Downregulation of presynaptic chloride concentration to low levels, such as those found in the soma of mature CA1 pyramidal neurons, would substantially reduce presynaptic $\mathrm{GABA}_{\mathrm{A}}$ receptor-mediated signaling, because the resulting shunting inhibition is considered not to be very effective in axons regarding the experimentally determined conductance densities (Jackson and Zhang, 1995; H. Alle and J. R. Geiger, unpublished observations). However, whether a chloride extrusion mechanism other than KCC2 is expressed in mossy fibers, which could bring presynaptic $\mathrm{GABA}_{\mathrm{A}}$ receptor reversal potential close to the negative resting membrane potential, is currently unknown.

In conclusion, depending on the duration of the highfrequency activity of a specific interneuron network and the actual presynaptic intracellular chloride concentration, the depolarization generated by presynaptic $\mathrm{GABA}_{\mathrm{A}}$ receptor activation could result in both facilitation and inhibition of AP-evoked transmitter release at the mossy fiber-CA3 synapse, thus contributing to the regulation of excitation in the dentate gyrus-CA3 network.

\section{References}

Alger BE, Nicoll RA (1979) GABA-mediated biphasic inhibitory responses in hippocampus. Nature 281:315-317.

Alle H, Geiger JRP (2006) Combined analog and action potential coding in hippocampal mossy fibers. Science 311:1290-1293.

Awatramani GB, Price GD, Trussell LO (2005) Modulation of transmitter release by presynaptic resting potential and background calcium levels. Neuron 48:109-121.

Banks MI, Pearce RA (2000) Kinetic differences between synaptic and extrasynaptic $\mathrm{GABA}_{\mathrm{A}}$ receptors in CA1 pyramidal cells. J Neurosci 20:937-948.
Berger T, Schwarz C, Kraushaar U, Monyer H (1998) Dentate gyrus basket cell $\mathrm{GABA}_{\mathrm{A}}$ receptors are blocked by $\mathrm{Zn}^{2+}$ via changes of their desensitization kinetics: an in situ patch-clamp and single-cell PCR study. J Neurosci 18:2437-2446.

Binda F, Bossi E, Giovannardi S, Forlani G, Peres A (2002) Temperature effects on the presteady-state and transport-associated currents of GABA cotransporter rGAT1. FEBS Lett 512:303-307.

Bischofberger J, Geiger JRP, Jonas P (2002) Timing and efficacy of $\mathrm{Ca}^{2+}$ channel activation in hippocampal mossy fiber boutons. J Neurosci 22:10593-10602.

Bischofberger J, Engel D, Li L, Geiger JRP, Jonas P (2006) Patch-clamp recording from mossy fiber terminals in hippocampal slices. Nat Protoc 1:2075-2081.

Bormann J, Hamill OP, Sakmann B (1987) Mechanisms of anion permeation through channels gated by glycine and $\gamma$-aminobutyric acid in mouse cultured spinal neurons. J Physiol (Lond) 385:243-286.

Eccles JC, Schmidt RF, Willis WD (1963) Pharmacological studies on presynaptic inhibition. J Physiol (Lond) 168:500-530.

Engel D, Jonas P (2005) Presynaptic action potential amplification by voltage-gated $\mathrm{Na}^{+}$channels in hippocampal mossy fiber boutons. Neuron 45:405-417.

Engelman HS, MacDermott AB (2004) Presynaptic ionotropic receptors and control of transmitter release. Nat Rev Neurosci 5:135-145.

Farrant M, Nusser Z (2005) Variations on an inhibitory theme: phasic and tonic activation of $\mathrm{GABA}_{\mathrm{A}}$ receptors. Nat Rev Neurosci 6:215-229.

Fiumelli H, Cancedda L, Poo M-M (2005) Modulation of GABAergic transmission by activity via postsynaptic $\mathrm{Ca}^{2+}$-dependent regulation of KCC2 function. Neuron 48:773-786.

Frahm C, Engel D, Draguhn A (2001) Efficacy of background GABA uptake in rat hippocampal slices. NeuroReport 12:1593-1596.

Galaretta M, Hestrin S (1997) Properties of $\mathrm{GABA}_{\mathrm{A}}$ receptors underlying inhibitory synaptic currents in neocortical pyramidal neurons. J Neurosci 17:7220-7227.

Geiger JRP, Jonas P (2000) Dynamic control of presynaptic $\mathrm{Ca}^{2+}$ inflow by fast-inactivating $\mathrm{K}^{+}$channels in hippocampal mossy fiber boutons. Neuron 28:927-939.

Geiger JRP, Bischofberger J, Vida I, Fröbe U, Pfitzinger S, Weber HJ, Haverkampf K, Jonas P (2002) Patch-clamp recording in brain slices with improved slicer technology. Pflügers Arch 443:491-501.

Gulyás AI, Sík A, Payne JA, Kaila K, Freund TF (2001) The KCl cotransporter, $\mathrm{KCC} 2$, is highly expressed in the vicinity of excitatory synapses in the rat hippocampus. Eur J Neurosci 13:2205-2217.

Gutiérrez R (2003) The GABAergic phenotype of the "glutamatergic" granule cells of the dentate gyrus. Prog Neurobiol 71:337-358.

Hines ML, Carnevale NT (1997) The NEURON simulation environment. Neural Comp 9:1179-1209.

Isaacson JS, Solís JM, Nicoll RA (1993) Local and diffuse synaptic actions of GABA in the hippocampus. Neuron 10:165-175.

Jackson MB, Zhang SJ (1995) Action potential propagation and propagation block by GABA in rat posterior pituitary nerve terminals. J Physiol (Lond) 483:597-611.

Jang I-S, Jeong H-J, Akaike N (2001) Contribution of the Na-K-Cl cotransporter on $\mathrm{GABA}_{\mathrm{A}}$ receptor-mediated presynaptic depolarization in excitatory nerve terminals. J Neurosci 21:5962-5972.

Jang I-S, Ito Y, Akaike N (2005) Feed-forward facilitation of glutamate release by presynaptic $\mathrm{GABA}_{\mathrm{A}}$ receptors. Neuroscience 135:737-748.

Jang I-S, Nakamura M, Ito Y, Akaike N (2006) Presynaptic GABA A $_{\text {recep- }}$ tors facilitate spontaneous glutamate release from presynaptic terminals on mechanically dissociated rat CA3 pyramidal neurons. Neuroscience 138:25-35.

Jones MV, Westbrook GL (1995) Desensitized states prolong GABA $_{\mathrm{A}}$ channel responses to brief agonist pulses. Neuron 15:181-191.

Katona I, Sperlágh B, Sík A, Köfalvi A, Vizi ES, Mackie K, Freund TF (1999) Presynaptically located CB1 cannabinoid receptors regulate GABA release from axon terminals of specific hippocampal interneurons. J Neurosci 19:4544-4558.

Kulik A, Vida I, Luján R, Haas CA, López-Bendito G, Shigemoto R, Frotscher $M$ (2003) Subcellular localization of metabotropic $G_{A B A}$ receptor subunits $\mathrm{GABA}_{\mathrm{B} 1 \mathrm{a} / \mathrm{b}}$ and $\mathrm{GABA}_{\mathrm{B} 2}$ in the rat hippocampus. J Neurosci 23:11026-11035.

Kullmann DM, Ruiz A, Rusakov DM, Scott R, Semyanov A, Walker MC 
(2005) Presynaptic, extrasynaptic and axonal $\mathrm{GABA}_{\mathrm{A}}$ receptors in the CNS: where and why? Prog Biophys Mol Biol 87:33-46.

Losonczy A, Biró AA, Nusser Z (2004) Persistently active cannabinoid receptors mute a subpopulation of hippocampal interneurons. Proc Natl Acad Sci USA 101:1362-1367.

Misgeld U, Deisz RA, Dodt HU, Lux HD (1986) The role of chloride transport in postsynaptic inhibition of hippocampal neurons. Science 232:1413-1415.

Mitchell SJ, Silver RA (2000) GABA spillover from single inhibitory axons suppresses low-frequency excitatory transmission at the cerebellar glomerulus. J Neurosci 20:8651-8658.

Neher E (1992) Correction for liquid junction potentials in patch clamp experiments. Methods Enzymol 207:123-131.

Nusser Z, Mody I (2002) Selective modulation of tonic and phasic inhibitions in dentate gyrus granule cells. J Neurophysiol 87:2624-2628.

Price GD, Trussell LO (2006) Estimate of the chloride concentration in a central glutamatergic terminal: a gramicidin perforated-patch study on the calyx of Held. J Neurosci 26:11432-11436.

Ruiz A, Fabian-Fine R, Scott R, Walker MC, Rusakov DA, Kullmann DM (2003) $\mathrm{GABA}_{\mathrm{A}}$ receptors at hippocampal mossy fibers. Neuron 39:961-973.

Sätzler K, Söhl LF, Bollmann JH, Borst JGG, Frotscher M, Sakmann B, Lübke JHR (2002) Three-dimensional reconstruction of a calyx of Held and its postsynaptic principal neuron in the medial nucleus of the trapezoid body. J Neurosci 22:10567-10579.

Schmitz D, Mellor J, Nicoll RA (2001) Presynaptic kainate receptor mediation of frequency facilitation at hippocampal mossy fiber synapses. Science 291:1972-1976.

Shu Y, Hasenstaub A, Duque A, Yu Y, McCormick DA (2006) Modulation of intracortical synaptic potentials by presynaptic somatic membrane potential. Nature 441:761-765.
Sieghart W (1995) Structure and pharmacology of $\gamma$-aminobutyric acid A receptor subtypes. Pharmacol Rev 47:181-234.

Sperk G, Schwarzer C, Tsunashima K, Fuchs K, Sieghart W (1997) GABA receptor subunits in the rat hippocampus I: immunocytochemical distribution of 13 subunits. Neuroscience 80:987-1000.

Szabadics J, Varga C, Molnár G, Oláh S, Barzó P, Tamás G (2006) Excitatory effect of GABAergic axo-axonic cells in cortical microcircuits. Science 311:233-235.

Tóth K, McBain CJ (1998) Afferent-specific innervation of two distinct AMPA receptor subtypes on single hippocampal interneurons. Nat Neurosci 1:572-578.

Turecek R, Trussell LO (2001) Presynaptic glycine receptors enhance transmitter release at a mammalian central synapse. Nature 411:587-590.

Turecek R, Trussell LO (2002) Reciprocal developmental regulation of presynaptic ionotropic receptors. Proc Natl Acad Sci USA 99:13884-13889.

Vida I, Frotscher M (2000) A hippocampal interneuron associated with the mossy fiber system. Proc Natl Acad Sci USA 97:1275-1280.

Vogt KE, Nicoll RA (1999) Glutamate and gamma-aminobutyric acid mediate a heterosynaptic depression at mossy fiber synapses in the hippocampus. Proc Natl Acad Sci USA 96:1118-1122.

Walker MC, Ruiz A, Kullmann DM (2001) Monosynaptic GABAergic signaling from dentate to CA3 with a pharmacological and physiological profile typical of mossy fiber synapses. Neuron 29:703-715.

Wei W, Zhang N, Peng Z, Houser CR, Mody I (2003) Perisynaptic localization of $\delta$ subunit-containing $\mathrm{GABA}_{\mathrm{A}}$ receptors and their activation by GABA spillover in the mouse dentate gyrus. J Neurosci 23:10650-10661.

Zhang SJ, Jackson MB (1993) GABA-activated chloride channels in secretory nerve endings. Science 259:531-534.

Zhang SJ, Jackson MB (1995) $\mathrm{GABA}_{\mathrm{A}}$ receptor activation and the excitability of nerve terminals in the rat posterior pituitary. J Physiol (Lond) 483:583-595. 